Indonesian Journal of Biotechnology, December, 2013

Vol. 18, No. 2, pp.123-132

\title{
The Phylogenetic Relationship Among Varieties of Lansium domesticum Correa Based on ITS rDNA Sequences
}

\author{
Laila Hanum ${ }^{1,2^{*}}$, Rina Sri Kasiamdari ${ }^{2,}$ Santosa $^{2}$, and Rugayah ${ }^{3}$
}

\author{
${ }^{1}$ Department of Biology, Faculty of Mathematics and Natural Science, Universitas Sriwijaya, \\ Palembang \\ ${ }^{2}$ Faculty of Biology, Universitas Gadjah Mada, Yogyakarta \\ ${ }^{3}$ Botany Divison, Research Center for Biology, Indonesia Institute of Science, Cibinong, Bogor, \\ Indonesia
}

\begin{abstract}
Lansium domesticum Corr. with vernacular name in Indonesian $d u k u$ has been reported containing therapeutic bioactive compounds, and some of these compounds shown to be potent antitumor, anticancer, antimalaria, antimelanogenesis, antibacteria, and antimutagenic activities. This plant is commonly known as $d u k u$, kokosan and langsat by the local community in Indonesia. The morphological appearance of all varieties is nearly the same, and identification of the varieties is very difficult for growers. Variation of DNA sequences of the ITS (Internal transcribed spacer) region can be used as a molecular character to determine the phylogenetic relationship of different varieties of $L$. domesticum. The aims of this study were to determine taxonomy status of duku, kokosan, and langsat, also phylogenetic relationship among varieties of L. domesticum based on ITS rDNA sequencing. DNA was isolated from leaves of plant and then amplified using F1 and R1 primers. Nucleotide sequences were identified using Sequence Scanner Software Programm version 1.0, nucleotide sequences from 18S, ITS1, 5.8S, ITS2 and 26S region, that has been mergered using EditSeq and SegMan in software Suite for Sequence Analysis DNASTAR Lasergene DM version 3.0.25. The results of study showed that DNA fragments ranging in size from 782-810 bp. Different pattern of DNA fragments indicated polymorphism among $d u k u$, kokosan, and langsat. Based on the results of the ITS rDNA sequencing and phylogenetic tree analysis. It was determined that Lansium and Aglaia are a separated genus with the similarity index value of 0.98 . Duku, kokosan and langsat were divided into two cluster, namely cluster kokosan-langsat and cluster duku with the similarity index value of 0.996 .
\end{abstract}

Keywords : Phylogenetic relationship, ITS region, L. domesticum, duku, kokosan, langsat

\section{Introduction}

Lansium domesticum is an important fruit tree and a highly variable species, with different forms that have been classified by some taxonomists as distinct species. In Southeast Asia, the plant has numerous common names, that is known as $d u k u$, kokosan and langsat (Indonesia); duku, langsak (Burmese); buahan, lansone, lansones, lanzon, lanzone (Philippine); langseh, langsep, lansa (Malay); duku, langsat, longkong (Thai) and

${ }^{*}$ Corresponding author:

Laila Hanum

Jurusan Biologi, FMIPA Universitas Sriwijaya, Palembang, Email : lailahanum@ymail.com
Bòn-bon (Vietnamese). It still occurs wild or naturalized in these area and is one of the major cultivated fruits. The greatest producers of L. domesticum are Malaysia, Thailand, the Philippines and Indonesia. On a small scale, this plant is also cultivated in Vietnam, Burma, India, Sri Lanka, Hawaii, Australia, Surinam and Puerto Rico (Yaacob and Bamroongrugsa, 1991; Lim, 2012). There are numerous varieties of $L$. domesticum, both the plants and the fruit. Overall, there are three main varieties of these fruits, in Indonesia i.e duku, kokosan and langsat (Yulita, 2011; Hanum et al., 2012).

Several parts of the plant have medicinal 
uses. The fruit peel is dried and burned to repel mosquitoes, it is also used to treat intestinal parasites and diarrhea. Powdered seeds are used to reduce fever, and the bark is used to treat malaria and scorpion stings (Naito, 1995; Loekitowati and Hermansjah, 2000; Saewan et al., 2006). Skin and leaf extracts of fruit of L. domesticum interrupt the lifecycle of Plasmodium falciparum, and are active towards a chloroquine-resistant strain of the parasite (T9) in vitro. Study indicates extracts of L. domesticum are potential source for compounds with activity against chloroquine-resistant strains of $P$. falcifarum (Yapp and Yap, 2003)

Cosmeceuticalvaluefrom its antioxidant, moisturizing, whitening and lightening effects. Dry extract of fruit is used for skin depigmentation and as a moisturizer (Tilaar et al., 2008; Manosroi et al., 2012). Extracts of this plant showed that strong inhibition of melanin production of B16 melanoma cells without significant cytotoxicity, presenting as a potential ingredient for skin-whitening cosmetics (Arung et al., 2009).

The air-dried fruit peel of L. domesticum yielded five onoceroid triterpenes; the airdried seeds yielded one onoceroid triterpene (lansionic acid) and germacrene D. Studies of the compounds showed various degrees of activity against $P$. aeruginosa, $B$ subtilis, $C$ albicans, A niger among others (Ragasa et al., 2006).

Phylogenetic relationship among duku, kokosan, and langsat in infraspecies level are still not clear. At the level of infraspecies, there are two different taxonomic status of duku, kokosan and langsat. Ridley (Lim, 2012) suggested that duku, kokosan and langsat (pisitan) belonging to two varieties which were L. dommesticum var. typica (duku) and L. dosmesticum var. pubescens (pisitan and kokosan), and Morton (1987) suggested that $L$. domesticum Corr. divided into two varieties, namely L. domesticum var. domesticum (duku) and L. domesticum var. pubescent (pisitan/ langsat). Another study by Yee et al. (1993), based on the observation of the anatomy of leaves, flowers, and fruits of duku separated them as varieties within the same species, namely L. domesticum. Morton (1987) and Yee et al. (1993) did not mentioned kokosan taxonomic status at the level of varieties. Lim (2012) stated that duku, kokosan and pisitan were grouped into two groups namely $L$. domesticum' duku group' and L. domesticum'langsat-longkong group'. According to Brandenburg (1986) and Hettercheid et al. (1996), the term group on crop can be equated varieties with the formal classification.

Molecular approach is an effective technique in genetic analysis, that can be used to determine genetic relatedness among duku, kokosan, and langsat in Indonesia. DNA sequences of the internal transcribed spacer (ITS) of the ribosomal RNA transcription unit have proven useful in resolving phylogenetic relationship of closely related taxa and in distinguishing species in plant (Hershkovitz and Zimmer, 1996; Muellner et al., 2008; Pandey and Ali, 2012).

Ribosomal DNA (rDNA) genes are organized in clusters of tandemly repeated units, each of which consists of coding regions (18S, 5.8S, and 28S) and 2 internal transcribed spacers (ITS) and 1 non-transcribed spacer (NTS) region. ITS sequences have been used successfully in studying phylogenetic and genomic relationships of plants at lower taxonomic levels and the ITS regions are therefore valuable in more discrete phylogenetic separation of closely related species, recognition of new species, determination of conspecificity between isolates, discrimination within a species, and differentiation between species and subspecies (Samigullina et al., 1998; Aktas et al., 2007; Song et al., 2012).

ITS an interesting subject for evolutionary/phylogenetic investigations, that which are found on either side of $5.8 \mathrm{~S}$ rRNA gene and are described as ITS1 and ITS2. The length and sequences of ITS regions of rDNA repeats are believed to be fast evolving and therefore may vary. The 
nucleotide sequence variation found in both of ITS-1 and ITS-2 is used extensively for the systematic analysis of closely related taxa, at least in part due to the speedy rate of evolutionary change characterizing these DNA regions. Universal PCR primers designed from highly conserved regions flanking the ITS and its relatively small size (600-700 bp) enable easy amplification of ITS region due to high copy number (Baldwin et al., 1995; Hershkovitz and Zimmer, 1996). The aims of this study to determine taxonomy status of $d u k u$, kokosan, and langsat, also phylogenetic relationship within different varieties of $L$. domesticum based on squencing of ITS rDNA.

\section{Materials and Methods \\ Plant materials}

Samples used in this study were 10 samples of $d u k u, k o k o s a n$, and langsat leaves from eight province in Indonesia with all of their vernacular names, summarized in Table 1.

\section{DNA isolation}

Total DNA was isolated from leaves using the Nucleon Phytopure Plant and Fungal DNA kit exraction RPN-8511/GE (Healthcare, U.K.) following the procedure described by Daryono and Natsuaki (2002).

\section{Amplification condition and agarose gel electrophoresis \\ DNA amplification was conducted}

based on Kasiamdari et al. (2002) with slight modifications. DNA were amplified by polymerase chain reaction (PCR) using forward primer F1 5'GATCGCGGCGGCGACTTGGGCGGTT C3' and reverse primer R1 5'GGTAG TCCCGCCTGACCTGGG3' (Muellner et al., 2008). Each sample was prepared by PCR reaction mixture, PCR kit (Megamix-Blue PCR Master mix: the enzyme Taq polymerase, 2.75 $\mathrm{mM} \mathrm{MgCl}$, $220 \mu \mathrm{M}$ dNTPs, and blue agarose loading dye) $22 \mu \mathrm{l}, 1 \mu \mathrm{l}$ primer F1 (100 pmol), $1 \mu \mathrm{l}$ primer R1 (100 pmol), DNA samples of 1 $\mu \mathrm{l}(10 \mathrm{ng} / \mathrm{ml})$. PCR reaction was performed by 30 cycles consisting of 3 phases, namely (i) pre-denaturation for 5 minute denaturation at $95^{\circ} \mathrm{C}$, (ii) denaturation for 1 minutes at $95^{\circ} \mathrm{C}$, (iii) annealing for 1 minutes at $60^{\circ} \mathrm{C}$, (iv) elongation for 2 minutes at $72^{\circ} \mathrm{C}$, and (v) postelongation for 10 minutes at $72^{\circ} \mathrm{C}$. All PCR products were separated by electrophoresis on $1.5 \% \mathrm{w} / \mathrm{v}$ agarose gel in 1xTBE, stained with $2.5 \mu \mathrm{l}$ GoodView (Fermentas), viewed under ultraviolet light and photographed using digital camera (Cannon).

\section{Purification and Sequence Analysis of ITS rDNA region.}

Purification and sequencing of ITS rDNA LOKI, LSle, LHat, LPung, LTan, LMat, DDre, DKom, DSle, and KKal was conducted by First BASE Laboratories (Singapore).

\section{Data Analysis}

Analysis of nucleotide sequences was

Table 1. List of samples used in the study

\begin{tabular}{cllll}
\hline No & Vernacular Name & Sample Code & Source of Materials & Province \\
\hline 1. & Duku Komering & DKom & Ogan Komering Ilir; Ogan Komering Ulu & South Sumatera \\
2. & Duku Sleman & DSle & Sleman & Yogyakarta \\
3. & Duku Dendan & DDre & Bengkalis & Riau \\
4. & Langsat OKI & LOKI & OKI & South Sumatera \\
5. & Langsat Sleman & LSle & Sleman & Yogyakarta \\
6. & Langsat Matesih & LMat & Karanganyar & Central Java \\
7. & Langsat Tanjung & LTan & Tabalong & South Kalimantan \\
8. & Langsat Punggur & LPung & Kubu Raya & West Kalimantan \\
9. & Langsat Hatu & LHat & Ambon & Ambon \\
10. & Kokosan Kaliurang & KKal & Kaliurang & Central Java \\
\hline
\end{tabular}


conducted by using Sequence scanner v1.0 (Applied Biosystem) program and Lasergene (DNASTAR Inc.). Program of basic local alignment search tool (BLAST) in website of DNA Data Bank of Japan (DDBJ) was used to find homolog sequences with data in GenBank. Multiple sequence alignment using ClustalW program in website DDBJ with using L. domesticum voucher Muellner130 (AY695587.1), L. domesticum voucher MWC2113 (AY695586.1); Aglaia rugulosa (AY695578.1); 2. Aglaia coriacea (EF491263.1); 3. Aglaia spectabilis (AY695580.1) 4. Aglaia korthalsii (EF491264.1); 5. Aglaia teysmanniana (AY695582.1) (outgroup) registered in GenBank as comparator.

Similiarities sequence analysis between samples were carried out using BioEdit programs (Hall, 1999) followed by construction of phylogenetic tree. Phylogenetic analysis was performed by Neighbor-Joining (NJ) methods using ClustalIX2 and MEGA5 programs, whereas genetic distance analysis relied on parameter Kimura-2 model. Grouping stability was calculated using 1000 Bootstrap value (analysis formation of branch of phylogenetic tree) (Tamura et al., 2011)

\section{Result and Discussion \\ Amplification of Duku, Kokosan, and Langsat ITS region}

PCR amplification using primers (F1 and R1) specifically recognized ITS region. The PCR products were visualized by agarose gel electrophoresis under UV light to chek the presence of amplified bands. Figure 1 showed clearly amplified bands (single band ) of $\sim 800$ bp that was generated from

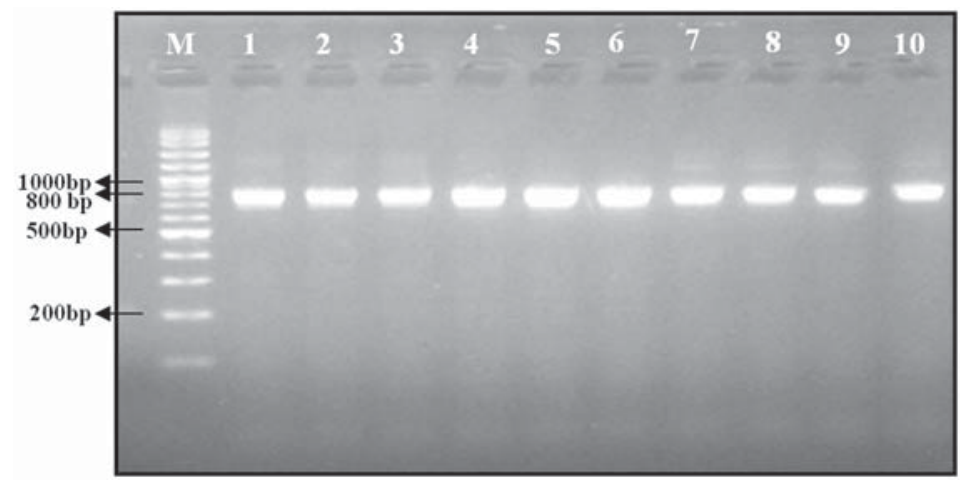

Figure 1. DNA fragments resulted from amplification using forward primer (F1) and reverse primer ( R1). M: DNA Marker (Ladder Vivantis 100 bp); 1. DKom; 2. DSle; 3. DDre; 4. LOKI; 5. LSle; 6. LHat; 7. KKal; 8. LMat; 9. LTan; 10. LPung.

Table 2. Fragment Sizes of Duku, Kokosan, and Langsat ITS region

\begin{tabular}{clccccccc}
\hline No & Sample & $\begin{array}{c}185 \\
(\mathrm{bp})\end{array}$ & ITS 1 (bp) & $5.8 S(\mathrm{bp})$ & $\begin{array}{c}\text { ITS2 } \\
(\mathrm{bp})\end{array}$ & $\begin{array}{c}285 \\
(\mathrm{bp})\end{array}$ & $\begin{array}{c}\text { ITS region } \\
(\text { ITS1; 5.8S; } \\
\text { ITS2) }(\mathrm{bp})\end{array}$ & $\begin{array}{c}\text { Total } \\
(\mathrm{bp})\end{array}$ \\
\hline 1. & DDre & 27 & 367 & 164 & 223 & 28 & 754 & 809 \\
2. & DKom & 28 & 367 & 164 & 230 & 24 & 761 & 813 \\
3. & DSle & 27 & 367 & 164 & 228 & 24 & 759 & 810 \\
4. & KKal & 28 & 365 & 164 & 224 & 24 & 753 & 805 \\
5. & LMat & 28 & 352 & 164 & 226 & 23 & 742 & 793 \\
6. & LPung & 26 & 365 & 164 & 226 & 24 & 755 & 805 \\
7. & LOKI & 26 & 366 & 164 & 224 & 28 & 754 & 808 \\
8. & LHat & 27 & 346 & 164 & 223 & 22 & 733 & 782 \\
9. & LTan & 26 & 364 & 164 & 226 & 22 & 754 & 802 \\
10. & LSle & 28 & 366 & 164 & 228 & 24 & 758 & 810 \\
\hline
\end{tabular}


all samples (DKom; DSle; DDre; LOKI; LSle; LHat; LMat; LTan; LPung; and KKal) using PCR with specific primers.

DNA sequencing of ITS region using forward primer (F1) and reverse primer (R1) produced nucleotide sequences with size ranged from 782-810 bp which consisted of 18S; ITS 1; 5.8S; ITS 2; and 28S region (Table 2).

The results in Table 2 also showed that ten samples of plant has produced size of varied fragment ITS region, ITS 1 ranged from 346-367 bp and ITS 2 ranged from 223 - 228 bp while $5.8 S$ region was more stable at the size of $164 \mathrm{bp}$. The results obtained in this studies, the same the report Muellner et al. (2005) on Aglaia is for ITS 1 ranging from 263-274 bp and ITS 2 ranged from $221-227 \mathrm{bp}$, while $5.8 \mathrm{~S}$ was stable at the size of $164 \mathrm{bp}$.

Variation of fragment size resulted from amplification of ITS region indicated that there was variation on the length of ITS region. Aktas et al. (2007) reported that the ITS1 length varied more than the ITS2, ITS1 varied in length from 482 to $1634 \mathrm{bp}$ and was longer than the ITS2 region (268$525 \mathrm{bp}$ ) in all Theileria isolates. Some rRNA genes were organized in clusters of tandemly repeated units, each of which consisted of coding regions (18S, 5.8S, and 28S) and 2 internal transcribed spacers (ITS) and 1 nontranscribed spacer (NTS) region. While the coding regions were evolutionarily conserved and had been utilized for phylogenetic inferences for major phyla (Hills and Dixon, 1991).
In this experiment, region of $5.8 \mathrm{~S}$ rRNA had similar fragment size of $164 \mathrm{bp}$ in all samples. Accoding to Hidayat and Pancoro (2001), region of 5.8S rRNA was more constant because of these gene encode rRNA which part constitute of ribosom small subunit to be a benefit to synthesis of protein. Ritland et al. (1993) reported that 5.8S region was relatively unvaried and ITS region do not encode an rRNA subunit and showed the expected greater sequence variation than that in the 5.8S.

Fragment sizes of ITS region (ITS $1,5.8 S$, and ITS2) in this study with size ranged from 733-761 bp were different with fragment sizes that had been reported by Muellner et al. (2005), in species of Aglaia (Meliaceae) including L. domesticum with size ranging between 627-664 bp in size. The fragment sizes of ITS regions resulted from this research were similar to fragment sizes that commonly found in Angiospermae. Baldwin et al. (1995) reported that generally fragment sizes of ITS region of Angiospermae approximately $700 \mathrm{bp}$ with the sizes of $\pm 300 \mathrm{bp}, \pm 165 \mathrm{bp}$, and $\pm 300 \mathrm{bp}$, respectively.

Nucleotide sequence analysis for comparing genetic information of $L$. domesticum and some species from Aglaia genus on ITS region was done compaty with foreknown sequences of DNA in GenBank databases. The homologous nucleotide sequences of each samples were analysed using BLAST (Basic local alignment search tool)

Table 3. Homology Search (Searching for highest similiaritas) on Duku, Kokosan, and Langsat relied on DDBJ.

\begin{tabular}{clllccc}
\hline No & Sample & \multicolumn{1}{c}{ High Similarity } & No Acession & Total Score & Query Coverage & Identity value \\
\hline 1. & DDre & L. domesticum voucher MWC2113 & AY695586.1 & 1277 & $92 \%$ & $99 \%$ \\
2. & DKom & L.domesticum voucher Muellner130 & AY695587.1 & 1321 & $91 \%$ & $99 \%$ \\
3. & DSle & L. domesticum voucher Muellner130 & AY695587.1 & 1290 & $92 \%$ & $99 \%$ \\
4. & KKal & L. domesticum voucher MWC2113 & AY695586.1 & 1266 & $92 \%$ & $99 \%$ \\
5. & LMat & L. domesticum voucher MWC2113 & AY695586.1 & 1279 & $92 \%$ & $99 \%$ \\
6. & LPung & L. domesticum voucher MWC2113 & AY695586.1 & 1029 & $92 \%$ & $99 \%$ \\
7. & LOKI & L. domesticum voucher Muellner130 & AY695587.1 & 1297 & $92 \%$ & $99 \%$ \\
8. & LHat & L.domesticum voucher Muellner130 & AY695587.1 & 1343 & $92 \%$ & $99 \%$ \\
9. & LTan & L. domesticum voucher MWC2113 & AY695586.1 & 1310 & $92 \%$ & $99 \%$ \\
10. & LSle & L. domesticum voucher Muellner130 & AY695587.1 & 1354 & $92 \%$ & $99 \%$ \\
\hline
\end{tabular}


Table 4. Values of Index of Similarity sequences of Duku, Kokosan, dan Langsat ITS rDNA region

\begin{tabular}{|c|c|c|c|c|c|c|c|c|c|c|c|c|c|c|c|c|c|}
\hline \multirow[b]{2}{*}{ Sample } & \multicolumn{17}{|c|}{ Similarity } \\
\hline & 1 & 2 & 3 & 4 & 5 & 6 & 7 & 8 & 9 & 10 & 11 & 12 & 13 & 14 & 15 & 16 & 17 \\
\hline 1 & & & & & & & & & & & & & & & & & \\
\hline 2 & 0,997 & & & & & & & & & & & & & & & & \\
\hline 3 & 0,995 & 0,998 & & & & & & & & & & & & & & & \\
\hline 4 & 0,998 & 0,992 & 0,998 & & & & & & & & & & & & & & \\
\hline 5 & 0,996 & 0,997 & 0,997 & 0,990 & & & & & & & & & & & & & \\
\hline 6 & 0,987 & 0,987 & 0,987 & 0,987 & 0,987 & & & & & & & & & & & & \\
\hline 7 & 0,987 & 0,987 & 0,987 & 0,987 & 0,987 & 0,996 & & & & & & & & & & & \\
\hline 8 & 0,987 & 0,987 & 0,987 & 0,987 & 0,987 & 0,998 & 0,996 & & & & & & & & & & \\
\hline 9 & 0,987 & 0,987 & 0,987 & 0,987 & 0,987 & 0,996 & 0,996 & 0,996 & & & & & & & & & \\
\hline 10 & 0,987 & 0,987 & 0,987 & 0,987 & 0,988 & 0,996 & 0,996 & 0,997 & 0,996 & & & & & & & & \\
\hline 11 & 0,987 & 0,987 & 0,987 & 0,987 & 0,988 & 0,997 & 0,996 & 0,996 & 0,996 & 0,998 & & & & & & & \\
\hline 12 & 0,987 & 0,987 & 0,987 & 0,987 & 0,987 & 0,996 & 0,996 & 0,996 & 0,998 & 0,996 & 0,992 & & & & & & \\
\hline 13 & 0,987 & 0,987 & 0,987 & 0,987 & 0,987 & 0,996 & 0,997 & 0,996 & 0,998 & 0,996 & 0,992 & 0,998 & & & & & \\
\hline 14 & 0,987 & 0,987 & 0,987 & 0,987 & 0,988 & 0.997 & 0,996 & 0,997 & 0,996 & 0,998 & 0,998 & 0,996 & 0,998 & & & & \\
\hline 15 & 0,987 & 0,987 & 0,987 & 0,987 & 0,987 & 0,998 & 0,998 & 0,996 & 0,997 & 0,996 & 0,995 & 0,997 & 0,997 & 0,997 & & & \\
\hline 16 & 0,987 & 0,987 & 0,987 & 0,987 & 0,988 & 0,996 & 0,996 & 0,997 & 0,997 & 0,999 & 0,998 & 0,996 & 0,998 & 0,998 & 0,996 & & \\
\hline 17 & 0,987 & 0,987 & 0,987 & 0,987 & 0,988 & 0,996 & 0,998 & 0,998 & 0,996 & 0,997 & 0,995 & 0,996 & 0,996 & 0,997 & 0,998 & 0,997 & \\
\hline
\end{tabular}

1. Aglaia rugulosa; 2. Aglaia coriacea; 3. Aglaia spectabilis; 4. Aglaia korthalsii; 5. Aglaia teysmanniana; 6. L. domesticum voucher MWC2113; 7. L. Tanjung; 8. L.domesticum voucher Muellner130; 9. DDre; 10. DKom; 11. LOKI; 12. KKal;13. LMat; 14. LHat; 15. LPung; 16. DSle; 17. LSle.

software versi 2.2.24 on server of DDBJ (DNA Data Bank of Japan) as mention in Table 3.

The result showed that all samples produced $99 \%$ similarity with L. domesticum voucher MWC2113 (AY695586.1) and L. domesticum voucher Muellner 130 (AY695587.1) but had no similiarity to another species (Table 3).

Similarity index values of DKom, DSle, DDre, LOKI, LSle, LHat, LMat, LTan, LPung, KKal, L. domesticum voucher MWC2113, L. domesticum vouchers Muellner130, and A. rugulosa, A. coriacea, A. spectabilis, A. korthalsii, and $A$. teysmanniana as outgroup were given on Table 4. The highest and lowest sequence similarity index values were 0.999 and 0.987 , respectively. Highest sequence similarity index value was found on DKom and LOKI meanwhile the lowest sequence similarity index values was found in all types of Aglaia was used as an out group with of duku, kokosan, langsat, L. domesticum voucher MWC2113 and L.domesticum voucher Muellner130.
Grouping pattern and relatedness among duku, kokosan, and langsat with A. rugulosa, A. coriacea, A. spectabilis, A. korthalsii, and $A$. teysmanniana as outgroup based on sequence similarity index value were analyzed with MEGA5 resulted as phylogenetic tree (Figure 2).

Figure 2 showed that the phylogenetic tree had two main clusters namely cluster I, which consisted of $d u k u, k o k o s a n$, and langsat and cluster II consisted of several species of Aglaia. Based on the clustering pattern suggested that Lansium and Aglaia is a monophyletic group that had a high similarity among the members. According to Hidayat and Pancoro (2008) in a phylogenetic approach, a group of organisms whose members have a lot of similarities of character is considered to have a very close relationship and estimated descended from a common ancestor.

Of these groupings could be defined separation between genus Lansium and 


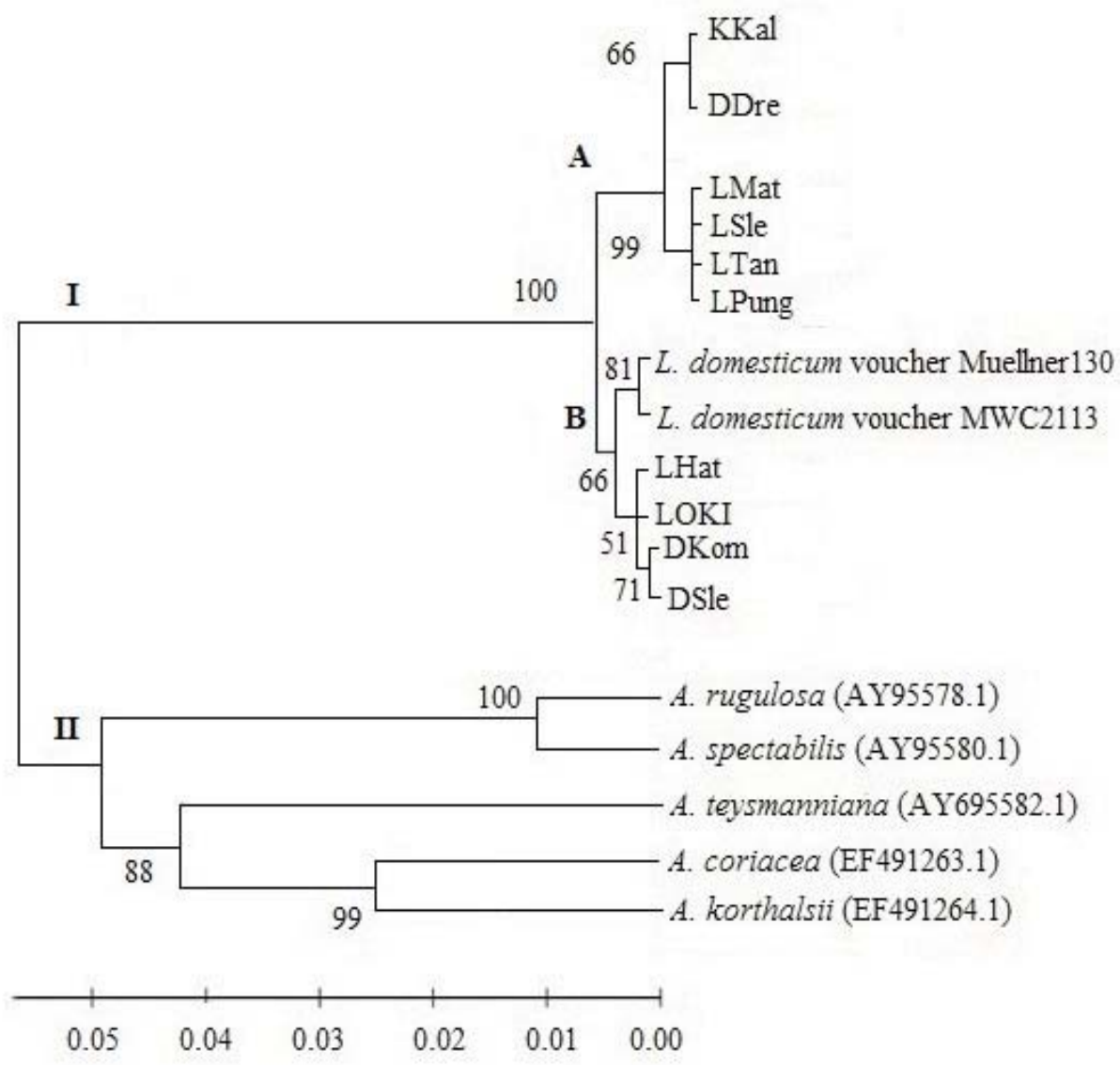

Figure 2. Phylogenetic tree of duku, kokosan, dan langsat based on ITS rDNA. The values on each of branch refers to values of bootstrap. Scala underneath of tree refers to genetic distance among samples.

Aglaia. Our results were different from previously described by Kostermans (1966), which stated that the placement of Lansium into Aglaia with three species, namely $A$. dookkoo Griff. (duku), A. aquea (Jack) Kosterm. (kokosan), and A. domestica (Corr. Emend. Jack) Pellegrin (langsat), and placement of Lansium as well as sectio of the genus Aglaia Lour. Our studies supported studies that had been reported by Pennington \& Style (1975) which stated Lansium and Aglaia were different genus. Muellner et al. (2005) also suggested that Lansium as a separate genus from Aglaia based on 16rps intron regions and secondary metabolites. This statement was reinforced by the results obtained by Muellner et al. (2008) based on the ITS region of Meliaceae plants, also got the same grouping pattern, that was Lansium and Aglaia separated into different groups and put Lansium and Aglaia on tribus Aglaieae.

Cluster I was divided into two subclusters, namely subcluster A and subcluster B. Sub cluster A consisted of two clusters, the first cluster consisted of KKal and DDre with the similarity index value of 0.998 . The inclusion of DDre in group kokosan is possibly occured by mistake in vernacular name by local communities. DDre was collected from Bengkalis Island, Pekan Baru. Recently, it is known that kokosan has only been recognized and is found in Java Island. Although based on fruit morphology DDre has similarities with kokosan but DDre has sweet fruit flavors like duku, unlike the kokosan that taste is very sour. Hanum et al (2012) reported based on RAPD approach stated DDre into the group kokosan. Based 
on our reseach of nucleotide sequences of the ITS region further strengthens position of DDre in the group of kokosan. The second cluster consisted of langsat namely LMat, LSle, LTan, and LPung with the similarity index value of 0.998 .

Subcluster B consisted of two sub-clusters, the first cluster consisted of L. domesticum voucher Muellner130 and L. domesticum voucher MWC2113 to the value of similarity index of 0.998. The second cluster consists of DSle, LHat, DKom, and LOKI. Similarity index values between DKom with LOKI are 0.999, while the value of similarity index between DSle with LHat are 0998. The inclusion of LOKI and LHat in group of $d u k u$ is possibly occurred by mistake in vernacular name and genetic variation occurred on LOKI and LHat. According to Suryanto (2003), genetic variation can occur because of alteration in nucleotides constituent of DNA. Genetic variation of duku, kokosan, and langsat likely occurred because there has been a cross-pollination and vegetative propagation.

Dispersal by humans can indirectly cause genetic variation. Genetic variations may occur due to natural mutations due to the influence of environmental stress the place of origin of the plant. Plants survive by adapting to their environment, breed and pass on their genes to the next generation. This process has been going on for decades causing genetic changes in LOKI dan LHat. Pandin (2010) stated that alteration occur due to the changes in reimbursement mechanisms and alteration in DNA nucleotide bases does not necessarily change the morphological characters, so that the use of markers that directly integrates with the genetics system will be better able to describe the actual state of the genome. Hanum et al. (2012) reported based on the RAPD approach of $d u k u$, kokosan, and langsat was known that LOKI and LHat were included in the group of $d u k u$.

Based on the results of the ITS rDNA sequencing and phylogenetic tree analysis, it can be determined that Lansium and Aglaia are separate genera with the similarity index value of 0.98 , and duku, kokosan and langsat were divided into two clusters, namely cluster kokosan-langsat and cluster duku with the similarity index value of 0.996 .

\section{References}

Aktas, M., Bendele, K.G., Altay, K., Dumanli, N., Tsuji, M. and Holman, P.J., 2007. Sequence polymorphism in the ribosomal DNA internal transcribed spacers differs among Theileria species. Veter. Parasitol., 147, 221-230

Arung, E.T., Kusuma, I.W., Christy, E.O., Shimizu, K. and. Kondo., 2009. Evaluation of medicinal plants from Central Kalimantan for antimelanogenesis. J. Nat. Med., 63(4), 473-480.

Baldwin, B.G., Sanderson, M.J., Porter, J.M., Wojciechowski, M.F., Campbell, C.S. and Donoghue MJ., 1995. The ITS region of nuclear ribosomal DNA: a valuable source of evidence on angiosperm phylogeny. Ann. Mo. Bot. Gard., 82, 247-277.

Brandenburg, W.A., 1986. Classification of cultivated plants. Acta Horticulturae., 182, 109-115.

Daryono, B.S. and Natsuaki, K.T., 2002. Application of random amplified polymorphic DNA markers for detection of resistent cultivars of melon (Cucumis melo L.) againts cucurbit viruses. Acta Horticulturae, 588, 321-329.

Hall, T.A., 1999. Bioedit: A user-friendly biological sequence aligment editor and analysis program for windows 95/98/ NT. Nuclei Acid Symphosium Series., 41, 95-98.

Hanum, L., R.S. Kasiamdari, Santosa and Rugayah. 2012. Genetic relatedness among duku, kokosan, and pisitan in Indonesia based on Random Amplified Polymorphic DNA Markers. Indonesian J. Biotech., 17(2), 121-131

Hidayat, T. dan Pancoro, A. 2001. Studi filogenetika molekular Anacardiaceae berdasarkan pada variasi urutan daerah internal transcribe spacer. Hayati., 8, 98101. 
Hidayat, T. dan Pancoro, A. 2008. Kajian filogenetika dan peranannya dalam menyediakan informasi dasar untuk meningkatkan kualitas sumber genetik anggrek. Jurnal Agro. Biogen., 4(1), 35-40.

Hillis, D.M. and Dixon, M.T., 1991. Ribosomal DNA: molecular evolution and phylogenetic inference. Q. Rev. Biol., 66, 411-453.

Hershkovitz MA and Zimmer EA., 1996 Conservation patterns in angiosperm rDNA ITS2 sequences. Nucleic Acid Res., 24, 2857-2867.

Hettercheid, W.L.A., van den Burg, R.G. and Brandenburg, W.A., 1996. An annotated history of the principles of cultivated plant classification. Acta. Bot. Neerl., 45(2), 123-134.

Kasiamdari, R.S., Smith, S.E., Smith, F.A. and Scott, E.S., 2002. Influences of the mychorrhizal fungus, Glomus coronatum and soil phosphorus on infection and disease caused by binucleate Rhizoctonia and Rhizoctonia solani on mung bean (Vigna radiata). Plant Soil., 238, 235-244.

Kostermans, A.J.G.H., 1966. A monograph of Aglaia sect. Lansium Kosterm. (Meliaceae). Reinwardtia., 7, 221-282.

Lim, T.K. (2012) Edible Medicinal Plant. $3^{\text {th }}$ Vol. Fruits. Springer. New York.

Loekitowati, H.P. dan Hermansjah., 2000. Studi pemanfaatan biji duku (Lansium domesticum) untuk obat diare secara in vitro. Jurnal Penelitian Sains., 7, 41-48.

Mabberley, D.J., Pannel, C.M. and Sing, A.M. 1995. Meliaceae. Flora Malesiana series I, Vol. 12, Part 1. Rijksherbarium/Hortus Botanicus, Leiden University, Leiden, Netherlands.

Morton, J. (1987) Langsat (Lansium domesticum corr.). In Fruits of Warm Climates (Morton, J.F.) p.201-203. Miami, FL: Florida Flair Books.

Manosroi, A., K. Kumguan, C. Chankhampan, W. Manosroi, and J. Manosroi., 2012b. Nanoscale gelatinase A (MMP-2) inhibition on human skin fibroblasts of Longkong (Lansium domesticum Correa) leaf extracts for anti-aging. J. Nanosci. Nanotechnol., 12(9), 7187-7197.

Muellner, A.N., Samuel R., Chase, M.W., Pannel, C.M. and Greger, H., 2005. Aglaia (Meliaceae): An evaluation of taxonomic concepts based on DNA data and secondary metabolites. American J. Bot. 92, 534-543.

Muellner, A.N., Samuel, R., Chase, M.W., Coleman, A. and Stuessy, T.F., 2008. An evaluation of tribes and generic relationship in Melioideae (Meliaceae) based on nuclear ITS ribosomal DNA. Taxon., 57(1), 98-108.

Naito, Y. (1995) Medicinal Herb Index in Indonesia. $2^{\text {nd }}$ ed. PT. Eisei Indonesia.

Pandey, A.K. and Ali, M.J., 2012. Intraspesific variation in Panax assamicus Ban. population based on internal transcribed spacer (ITS) sequences of nrDNA. India J. Biotech., 11, 30-38.

Pandin, D.S., 2010. Penanda DNA untuk pemuliaan tanaman kelapa (Cocos nucifera L). Perspektif., 9(1), 21-35.

Pannel, C.M. 1992. A Taxonomy monograph of the genus Aglaia Lour. (Meliaceae). Kew Bulletin, Additional series 16. Her Majesty's Stationery office, London.

Pennington, T.D. and Styles, B.T. 1975. A generic monograph of the Meliaceae. Blumea., 22, 419-540.

Ragasa, C.Y., Labrador, P. and Rideout, J.A. 2006. Antimicrobial terpenoid from Lansium domesticum. Philippine Agr. Sci., 89(1), 101-105.

Ritland, C.E., Ritland, K. and Straus, N.A., 1993. Variation in the ribosomal internal transcribed spacer (ITS1 and ITS2) among eight taxa of the Mimulus guttatus species complex. Mol. Biol. Evol., 10(6), 12731288.

Saewan, N., Sutherland, J.D. and Chantrapromma, K., 2006. Antimalarial tetranorterpenoids from the seeds of Lansium domesticum Corr. Phytochem., 67, 2288-2293.

Samigullina, T.H., Valiejo-Romana, K.M., Troitskya, A.V., Bobrovaa, V.K., Filinb, 
V.R., Martinc, W., and Antonova, A.S., 1998. Sequences of rDNA internal transcribed spacers from the chloroplast DNA of 26 bryophytes: properties and phylogenetic utility. FEBS Letters., 422, 47-51

Song, H.X., Gao, S.P., Jiang, M.Y., Liu G.L., Yu, X.F., and Chen, Q.B., 2012. The evolution and utility of ribosomal ITS sequences in Bambusinae and related species: divergence, pseudogenes, and implications for phylogeny J. Genetics., 91(2), 129-139.

Suryanto, D. 2003. Melihat keanekaragaman organisme melalui beberapa teknik genetika molekular. Digital library. PS. Bioteknologi, FMIPA-USU.

Tamura, K., Peterson, D., Peterson, N., Stechner, G., Nei, M., and Kumar, S., 2011. MEGA 5: Moleculer evolutionary genetic analysis using maximum likehood, evolutionary distance, and maximum parsimony methods. Mol. Biol. Evol. Doi:10.1093/molbev/msr121.

Tilaar, M., Wih W.L., Ranti A.S. Wasitaamadja, S.M., Suryaningsih, F.D. Junardy, F.D. and Maily., 2008. Review of Lansium domesticum Corrêa and its use in cosmetics. Boletín Latinoamericano y del Caribe de Plantas Medicinales y Aromáticas., 7(4), 183-189.

Yaacob, O. and Bamroongrugsa, N., 1991. Lansium domesticum Correa In: Verheij, E.W.M. and Coronel, R.E. (Editors). Plant Resources of South-East Asia No. 2: Edible fruits and nuts. Pudoc, Wageningen, The Netherlands. pp.186190

Yapp, D.T.T and Yap, S.Y., 2003. Lansium domesticum: skin and leaf extracts of this fruit tree interrupt the lifecycle of Plasmodium falciparum and are active towards a chloroquine-resistant strain of the parasite (T9) in vitro. J. Ethnopharmacol., 85(1), 145-150.

Yee, T.F., Rao, A.N. and Goh, C.J., 1993. Systematic anatomy of duku and langsat-
Lansium domesticum. J. Singapore Natio. Acad. Sci., 20, 37-50.

Yulita, K.S., 2011. Genetic variation of Lansium domesticum Corr. accessions from Java, Sumatra and Ceram based on Random Amplified Polymorphic DNA fingerprints. Biodiv., 12(3), 125-130. 